\title{
Butterfly Species Diversity and Abundance in University of Ibadan Botanical Garden, Nigeria
}

\author{
Abideen Abiodun Alarape ${ }^{1}$, James Kehinde Omifolaji ${ }^{1,2}$, Georgina Samuel Mwansat ${ }^{3}$ \\ ${ }^{1}$ Department of Wildlife and Ecotourism Management, University of Ibadan, Ibadan, Nigeria \\ ${ }^{2}$ Department of Forestry and Wildlife, Federal University Dutse, Dutse, Nigeria \\ ${ }^{3}$ Department of Zoology, University of Jos, Jos, Nigeria \\ Email: $\underline{\text { h2ofolaji@gmail.com }}$
}

Received 24 January 2015; accepted 1 August 2015; published 6 August 2015

Copyright (C) 2015 by authors and Scientific Research Publishing Inc.

This work is licensed under the Creative Commons Attribution International License (CC BY). http://creativecommons.org/licenses/by/4.0/

c) (i) Open Access

\begin{abstract}
Understanding the significance of butterflies in an ecosystem as an environmental healthy indicator and pollination of flowering plants is crucial to achieving sustainability and conservation of floral diversity. The aim of the study was to investigate the butterfly species diversity and abundance and compare the relationship between physical factor and butterfly species. Line transect were used to survey three habitats around botanical garden with scooped-net between June and July, 2010. Diversity varied from habitat to habitat. A checklist was made comprising a total of 57 butterfly species that were surveyed belonging to 9 families. There was a relationship between temperature and butterfly species diversity and abundance. There was no correlation between physical factors (relative humidity and temperature) and the total number of species and families. Moreover, butterfly numbers were not related to relative humidity in any species and family. However, temperature was significantly correlated with species. Therefore, understanding of the factors that affect butterfly species diversity and abundance in University of Ibadan Botanical Garden is important for conservation.
\end{abstract}

\section{Keywords}

Butterfly, Species, Botanical Garden, Diversity

\section{Introduction}

Insect comprises more than half of earth diversity of species [1]. Butterflies are a taxonomically well studied 
group, which have received a reasonable amount of attention throughout the world [2], yet even within genera containing very common and wide spread species, our understanding of true species diversity may prove to be startling below common expectation [3] [4]. They have been studied systematically since the early $18^{\text {th }}$ century and about 20,000 species are documented worldwide by 1998 [5]. This figure is not constant because of continuous addition of new butterflies' species. Many butterflies' species are strictly seasonal indicators in term of anthropogenic disturbance and habitat quality [6]. Lepidoptera community assembly and the factors which influence it have long been a topic of interest to ecologist and conservationists. Human dominated landscape form a substantial and ever increasing amount of the earth's surface. These modified habitats often influence butterfly species and their dynamics [7] [8].

Arthropods are good indicators of habitats biodiversity because they respond quickly to environmental changes, and are highly diverse taxon. Lepidoptera (butterflies and moths) are the second largest order of arthropods and are most easily identified, making them particularly useful for biodiversity survey [9]-[12]. Butterflies occur in a wide range of situations but are particularly characteristics of humid tropical forests, in which the known species occur. Two important aspect of diversity are species richness [13] and relative abundance of individuals [14]. Species richness is a critical variable in conservation planning and natural resource management.

A large proportion of the earth's planets plant species including many trees depends on insects to pollinate their flowers. In turn, we and other land-dwelling animals depend on plant [15]. Disappearance of insects could lead to extinction of earth's animals because of the disappearance of so much plant life. Fortunately, insect has been around for at least 400 million years, and are phenomenally successful form of life. Today they are by far the planets most diverse, abundant and successful insect. The roles that the insects play in nature require us to understand how insects and other organisms living in a biological community interact with living and non-living environment [16]. Among insects, butterflies are the most studied group in southern Nigeria, butterfly species have been documented since turn of $19^{\text {th }}$ century [17]. Later he made a preliminary survey of butterflies of Olokemeji forest reserve and Agege in Lagos state [18]. Also [19] made a detailed survey of butterflies of International Institute for Tropical Agriculture (IITA) forest, Ibadan and recorded nearly 149 species. The purpose of present investigation is to assess species richness of butterflies, provide species list and determine the physical factors affecting the distribution of butterfly species in the study area.

\section{Materials and Methods}

\subsection{Study Area}

University of Ibadan Botanical Garden is located within the University of Ibadan campus which is situated 6 kilometers to the North of the city of Ibadan $\left(7^{\circ} 26^{\prime} \mathrm{N}\right.$ and $\left.3^{\circ} 54^{\prime} \mathrm{E}\right)$ at a mean altitude of 277 meters above sea level (Figure 1). It covers an area of 100 acres on the north of the site. The topsoil is freely drained, fairly acidic and of moderate fertility with colluvial deposits in the valley. The University of Ibadan is located in the northern limit of lowland rainforest zone. It lies in a transitional zone between the rainforest and derived savanna zone with annual rainfall of about $1220 \mathrm{~mm}$ of double peak during June and August which lasts for almost 8 months (April to October) and dry season between November and March. The vegetation of the area is rich with highly diverse species comprising of a wide variety of woody trees, shrubs, collection of herbs, palms and climbers which are well represented.

\subsection{Monitoring (Line Transect)}

Butterfly species was assessed quantitatively across different habitats with sweep net and trapping methods. The entire botanical garden was divided into 3 different habitats which were stratified on the basis of flora composition. A $0.5 \mathrm{~km}$ transect was established at every site and attempts were made to catch every butterfly seen following Pollard's transect walking technique [20]-[22]. In total, 12 transect walks $(500 \times 10 \mathrm{~m})$ per site were done, Global Positioning Systems (GPS) readings were taken at the beginning, a few points along transects (especially curved points) and the end of transects. Weather conditions were noted and no netting was done under the following conditions: 1 ) wind $>3$ on the Beaufort scale; 2) raining or very wet vegetation; and 3) cloudy and cold days. Random sweep netting formed the basis for species lists rapid biodiversity assessments [23]. Sampling was carried out at different habitats from 21st June to 9th July, 2010. Modifications of the line transect count as per [24] was used to determine the butterfly abundance and richness. In this method $500 \mathrm{~m}$ line transects 


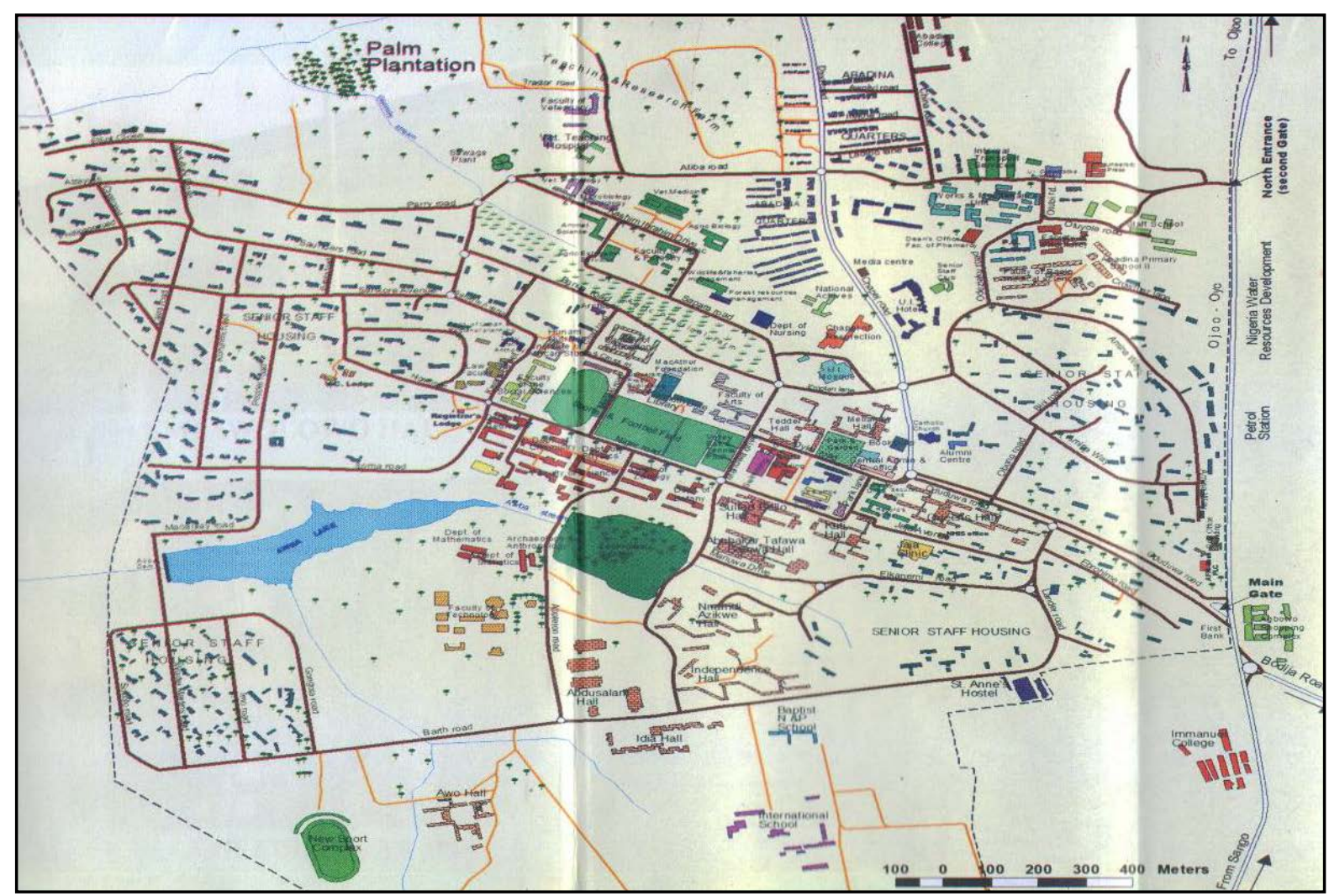

Figure 1. Map of University of Ibadan showing the study area.

was set up in each habitat. Each transect was slowly traversed at a uniform pace of 40 minutes at each habitats from 9 - 11 am during good weather period (no heavy rain or strong winds). Butterfly species were recorded around a radius of five meter from the observer covering his either sides, above and front. This method is suitable for the survey of butterfly in a range wide of habitats including tropical forest [15] [25]-[27]. All the individual species were identified by using standard guide [28].

\subsection{Data Analysis}

Data was analyzed by using SPSS 17. Butterfly species, individual diversity and abundance were calculated by using descriptive statistics. One-way ANOVA was used to determine if the difference in family and species richness across habitat were significant. The means of species richness were calculated. Pearson's correlation was used to determine if there were significant relationships between physical factors and species richness.

\section{Results}

A checklist of butterfly species of 57 species and 698 individuals belonging to 9 families of butterfly were observed (Appendix 1 and Table 1), Pieridae has both the highest percent of species and individuals (38\%, 57.9\% respectively) while Ithiomidae and Rioninidae has both the least percent of species and individuals (Table 1). A total of 48 Species were observed in the garden transect, 28 species each were also observed in the forest and cultivated habitat respectively (Figure 2). None of the physical factors was significantly related to the butterfly families' abundant at 0.01 level (2-tailed) (Table 2). It shows that a correlation exists between species abundance and temperature except for relative humidity on species and families as shown in Table 2. This result is consistent with [29]. It may reflect the difference between tropical and temperate climatic patterns. However, lack of significant correlations between relative humidity and temperature and butterfly families indicated that relative humidity and temperature did not have an important influence on butterfly families.

The most abundance species and individual are given in Table 1. A total of 698 individuals from 9 families 
Table 1. Frequency distribution of butterfly species encountered according to family in the botanical garden, university of Ibadan.

\begin{tabular}{ccc}
\hline Family & Number of Species (\%) & Individual (\%) \\
Pieridae & $22(38.5)$ & $404(57.9)$ \\
Nymphalidea & $12(21)$ & $132(18.9)$ \\
Heliconidae & $6(10.5)$ & $75(10.7)$ \\
Lycaenidae & $2(3.5)$ & $8(1.1)$ \\
Ithiomidae & $1(1.75)$ & $6(0.9)$ \\
Rioninidae & $1(1.75)$ & $2(0.3)$ \\
Dananidae & $4(7)$ & $36(5.1)$ \\
Papilonidae & $2(3.5)$ & $6(0.9)$ \\
Satyridae & $7(12)$ & $29(4.1)$ \\
Total & 57 & 698 \\
\hline
\end{tabular}

Source: Field survey, 2010.

Table 2. Correlation between butterfly abundance and species richness and physical factors.

\begin{tabular}{ccc}
\hline Physical factors & Humidity & Temperature $\left({ }^{\circ} \mathrm{C}\right)$ \\
\hline Family & -0.630 & 0.521 \\
Species & -0.264 & $0.828^{* *}$ \\
\hline
\end{tabular}

${ }^{* *}$ Correlation is significant at the 0.01 level (2-tailed). Source: Field survey, 2010.

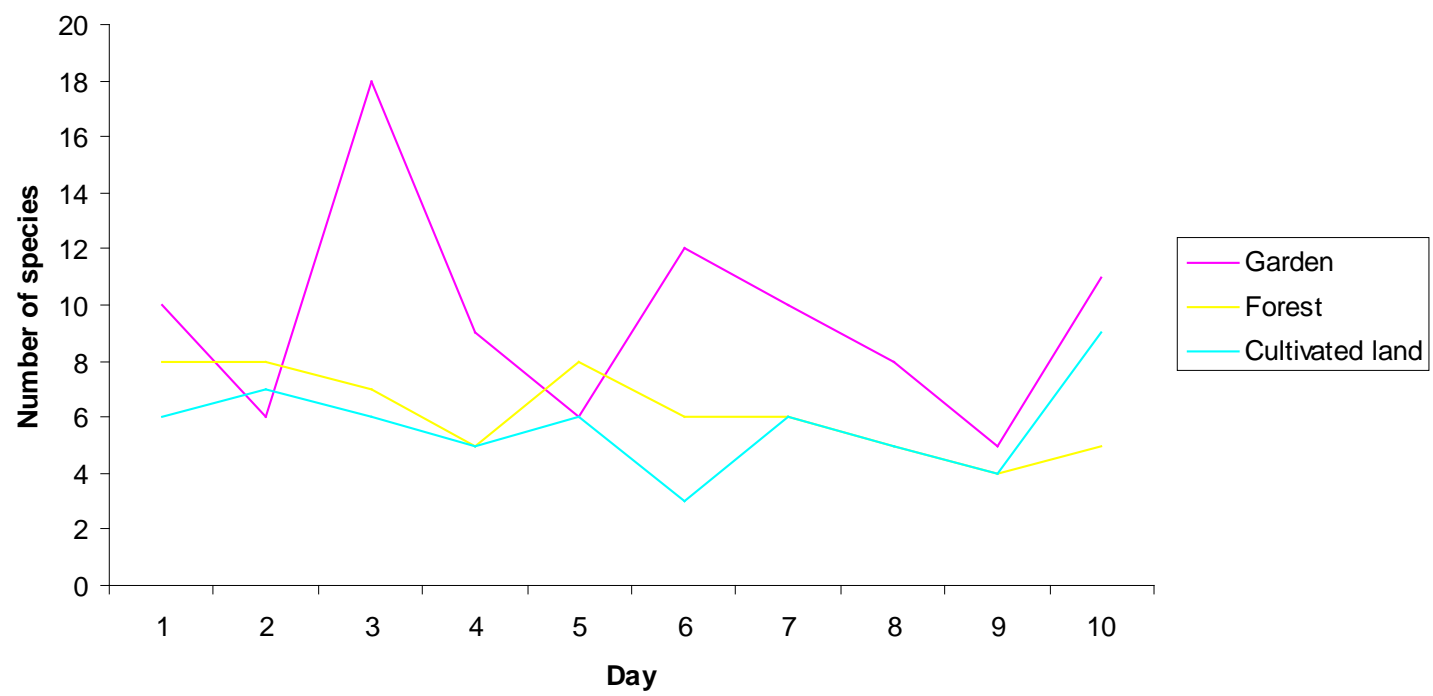

Figure 2. Number of butterflies species richness/transect in the University of Ibadan Botanical Garden. Source: Field survey, 2010.

were observed and identified. Pieridae species with 404 individuals, 57.9\% had the largest number followed by the Nymphalidae species 132 individuals, Heliconidae species 75 individuals while Ithiomidae and Papilonidae species had the least 6 individuals, 0.9\% each respectively (Table 1). Overall butterfly species/day effort curve across the three habitats shows that garden habitat recorded 19 species/day while cultivated habitat had the least species of butterfly per day (Figure 3). Species richness across habitat/transect shows that garden habitat has the highest number of species recorded during the study while both the forest and cultivated habitats have 28 species each encountered during the study as shown in Figure 2. The study shows that garden habitat has the highest 


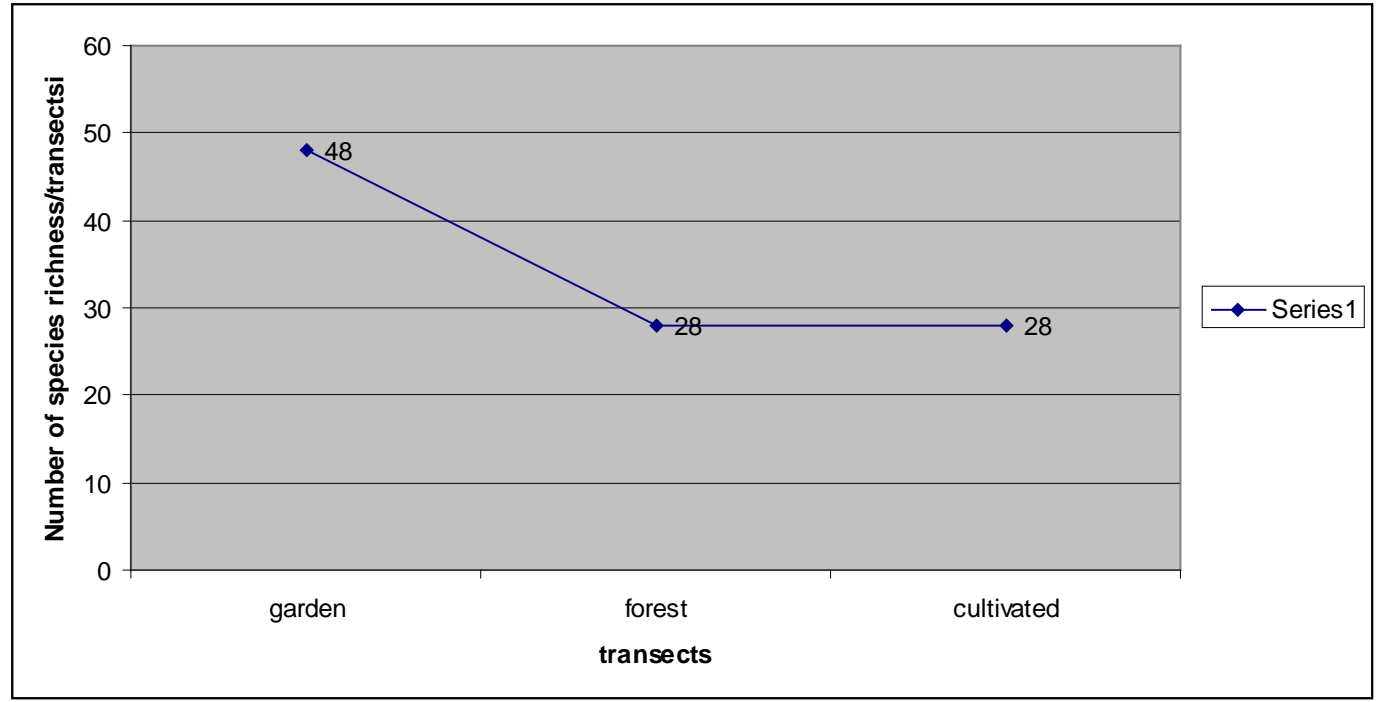

Figure 3. Overall butterfly species/day effort curve across the three habitats in the University of Ibadan Botanical Garden, Nigeria. Source: Field survey, 2010.

mean number of species diversity of 9.5 while both the forest and cultivated habitats have mean number of 6.2 and 5.7 respectively (Figure 4).

\section{Discussion}

\subsection{Species Richness, Abundance and Diversity}

A total number of 57 species belonging to 9 families in the order Lepidoptera were recorded and it indicated that the habitat had a considerable diversity and abundant number of butterfly species. Out of these, Pieridae were the most common with 22 species, followed by Nymphalidae (12 species), Satyridea (7 species), and the least number of species was observed in Ithiomidae and Rioninidae by 1 species each. Pieridea was the dominant family, accounting for $38 \%$ of species and $57.9 \%$ of individuals recorded (Table 1 ).

A total of 698 individual from 3 habitats/transects were observed and identified (Appendix 1). Forty eight species of butterfly were observed in garden habitat while forest and cultivated habitats reached 28 species each respectively (Figure 3). The study revealed that in the garden habitat the individual among species were evenly distributed during the survey period, indicating that some species were more abundant than the others (Figure 4 \& Figure 5). The abundance of individual of a species at any given point on a temporal scale was again dependent on abiotic and biotic environmental factors.

The structural complexity of habitat and diversity of vegetation forms have been shown to correlate with animal and insect species diversity. The herbivores are more influenced by the food quality. Host plants are utilized only when sufficient resources (nectar) are also available [15] [30]-[32]. Successful butterfly habitat must therefore include sufficient larval and adult food resources. In the present study, the maximum number of species and individual were observed in garden area, where availability of diverse plants and access to host plants viz., Crotalaria verucosa, Tridax procumbens, Mimosa pudica, Chromolaena odorata, Lantana camara and ornamental flowering plants promoted the butterfly richness. The butterfly distribution are expected to reflect the distribution of their host plants even at scales and type of vegetation may reflect difference in the composition of butterfly species among habitats at the generic and family level [15] [33]. Figures 2-5 also confirmed the above finding.

\subsection{The Relationship between Physical Factors and Butterfly Diversity}

In this study none of the physical factors was significantly related to the families or species richness. It may reflect the difference between tropical and temperate climatic patterns. Environmental fluctuation in temperate region is relatively greater and may have severe effect on the abundance and species richness of butterflies. Relative 


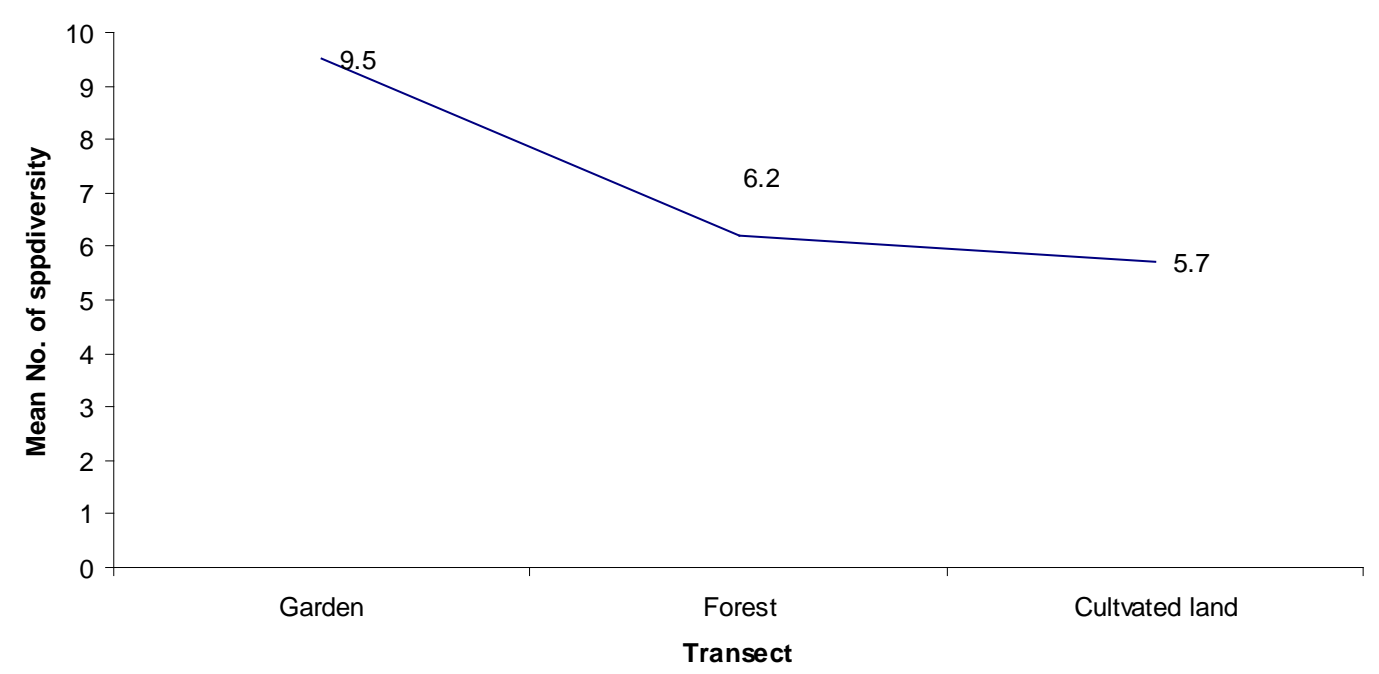

Figure 4. Butterfly families diversity in each transect at the University of Ibadan Botanical Garden. Source: Field survey, 2010.

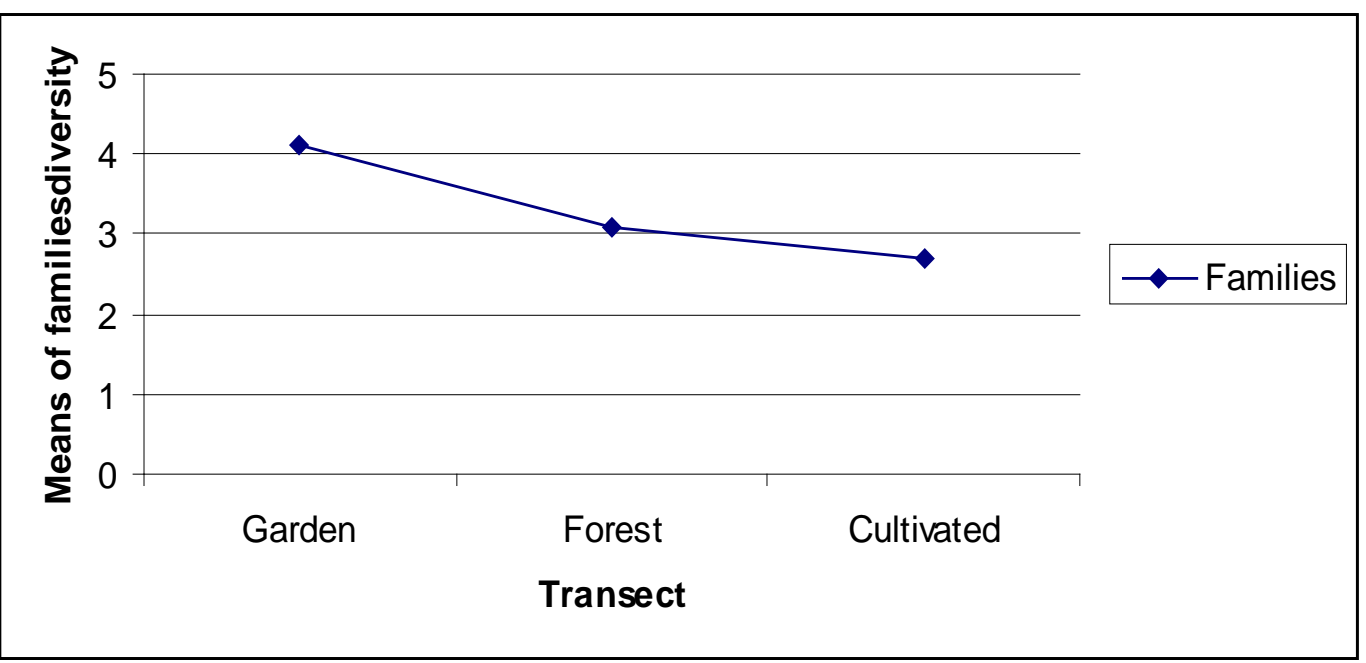

Figure 5. Butterfly species diversity in each transect at the University of Ibadan Botanical Garden. Source: Field survey, 2010.

humidity and rainfall were negatively correlated with the number of species in Kunte and Pollard's studies [24] [33]. Relative humidity and temperature had no correlation with the families and species number while temperature was significantly correlated with the number of individuals and species of Pieridae and Lycaenidae. The finding corroborated with some other field research [24] [34]. Butterflies of this family often sun themselves. High temperature also facilitates oviposition, courtship behaviour, and larval development. In addition, temperature promotes the growth of food plants [34].

\section{Conclusion}

The University of Ibadan botanical garden harbour floral diversity that supports conservation of butterfly species diversity and abundance in the area. As a result of the data obtained from this survey, it showed that the number of species of butterflies observed in garden habitat was consistently greater than both the forest and cultivated habitat. The butterfly of the family Pieridae were the most abundant species and had the highest individual species observed during the study; also both the family Ithiomidae and Rioninidae had the least number of species observed respectively from the survey. The result from the study also showed that physical factors had no relationship with butterfly families and species richness. 


\section{References}

[1] May, P.G. (1992) Flower Selection and the Dynamics of Lipid Reserves in two Nectarivorous Butterflies. Ecology, 73, 2181-2191. http://dx.doi.org/10.2307/1941466

[2] Ghazoul, J. (2002) Impact of Logging on the Richness and Diversity of Butterflies in a Tropical Dry Forest in Thailand. Biodiversity and Conservation, 11, 521-541. http://dx.doi.org/10.1023/A:1014812701423

[3] Ackery, P.R. (1987) Diversity and Phantom Competition in Africa Acraeine Butterflies. Biological Journal of Linneann Society, 30, 291-297. http://dx.doi.org/10.1111/j.1095-8312.1987.tb00303.x

[4] Willmott, K.R., Hall, J.P.W. and Lamas, G. (2001) Systematics of Hypanartia (Lepidoptera: Nymphalidae: Nymphalidae), with a Test for Geographical Speciation Mechanisms in the Andes. Systematic Entomology, 26, 369-399. http://dx.doi.org/10.1046/j.1365-3113.2001.00157.x

[5] Happner, J.B. (1998) Classification of Lepidoptera. Part 1: Introduction. Holarctic Lepidoptera, 5, 1-148.

[6] Kocher, S.D. and Williams, E.H. (2000) The Diversity and Abundance of North America Butterflies, Vary with Habitat Disturbance and Geography. Journal of Biogeography, 27, 785-794. http://dx.doi.org/10.1046/j.1365-2699.2000.00454.X

[7] Gascon, C., Lovejoy, T.E., Bierregaard, R.O., Malcolm, J.R., Stouffer, P.C, Vasconceleos, H.L., Laurance, W.F., Zimmerman, B., Tocher, M. and Borges, S. (1999) Matrix Habitat and Species Richness in Tropical Forest Butterflies. Biological Conservation, 91, 223-229. http://dx.doi.org/10.1016/S0006-3207(99)00080-4

[8] Rickets, T.H., Daily, G.C. and Fay, J.P. (200l) Countryside Biogeography of Moths in a Fragmented Landscape: Biodiversity in Native and Agricultural Habitats. Conservation Biology, 15, 378-388.

[9] Erhardt, A. (1985) Diurnal Lepidoptera: Sensitive Indicators of Cultivated and Abandoned Grassland. Journal of Applied Ecology, 22, 849-861. http://dx.doi.org/10.2307/2403234

[10] Inuoye, D.W. (2001) Role of Pollinator in Encyclopedia of Biodiversity, Volume 4. Academy Press, London, $732-730$.

[11] Kremen, C. (1994) Biological Inventory Using Target Taxa: A Case Study of Butterflies in Rainforest of Madagascar. Journal of Ecological Applications, 4, 407-422. http://dx.doi.org/10.2307/1941946

[12] Tiple, A.D. and Arun, M.K. (2009) Butterfly Species Diversity, Habitats and Seasonal Distribution in and Nagpur City, Central India. Journal of Natural History, 43, 855-884. http://dx.doi.org/10.1080/00222930802610568

[13] Landau, D., Prowell, D. and Carlton, C.E. (1999) Intensive versus Long-Term Sampling to Access Lepidopteran Diversity in a Mixed Mesophytic Forest. Journal of Conservation Biology and Biodiversity, 92, 435-441.

[14] Hammond, P.C. and Miller, J.C. (1998) Comparism of the Biodiversity of Lepidoptera within Three Forested Ecosystems. Journal of Conservation Biology and Biodiversity, 91, 323-328.

[15] Ramesh, T., Hussain, K.J., Selvanayagam, M., Satpathy, K.K. and Prasad, M.V.R. (2010) Patterns of Diversity, Abundance and Habitat Association of Butterflies Communities in Heterogeneous Landscapes of Department of Atomic Energy (DAE) Campus at Kalpakkam, South India. International Journal of Biodiversity and Conservation, 2, 75-85.

[16] Miller, G.T. (2006) Environmental Science, Working with Earth. 10th Edition, Brooks Cole Thompson, Nelson.

[17] Larsen, T.B. (1987) Butterfly in India. Oxford University Press, New Delhi.

[18] Boonvanno, K. (2001) Physical Effects on Butterfly Diversity at Ton Nga Chang Wildlife Sanctuary, Southern Cyprus. Science Asia, 49, 177-188. Southern Thailand. NAT. HIST. BULL. SIAM Soc, 49, 177-188.

[19] Warren, R.D. (2010) Butterfly of International Institute of Tropical Agriculture (IITA), Ibadan. International Institute of Tropical Agriculture, Ibadan.

[20] Pollard, E., Elias, D.O., Skelton, M.J. and Thomas, J.A. (1975) A Method of Assessing the Abundance of Butterflies in Monk's Wood National Nature Research in 1973. Entomologist's Gazette, 26, 79-87.

[21] Pollard, E. (1977) A method for Assessing Changes in Abundance of Butterflies. Biological Conservation, 12, 115-134. http://dx.doi.org/10.1016/0006-3207(77)90065-9

[22] Pollard, E. and Yates, T.J. (1993) Monitoring Butterflies for Ecology and Conservation. Chapman \& Hall, London.

[23] Hambler, C. (2004) Conservation Studies in Biology. Cambridge University Press, Cambridge.

[24] Kunte, K.J. (1997) Seasonal Patterns in Butterfly Abundance and Species Diversity in Four Tropical Habitats in Northern Ghats. Journal of Biological Science, 22, 593-603. http://dx.doi.org/10.1007/bf02703397

[25] Walpole, M.J. and Sheldon, I.R. (1999) Sampling Butterfly in Tropical Rainforest: An Evaluation of a Transect Walk Method. Journal of Biological Conservation, 87, 85-91.

[26] Caldas, A. and Robbin, R.K. (2003) Modified Pollard Transects for Assessing Tropical Butterfly Abundance and Diversity. Journal of Biological Conservation, 110, 211-219.

[27] Prun, R.O. (2006) Anatomical Diverse Butterfly Scales all Produce Structural Colours by Coherent scattering. Journal 
of Experimental Biology, 209, 748-765. http://dx.doi.org/10.1242/jeb.02051

[28] Riley, N.D. (1975) A Field Guide to the Butterflies of the West Indies. William Collins Sons and Co Limited, London.

[29] Boovanno, K., Watanasit, S. and Permkam, S. (2000) Butterfly Diversity at Ton Nga Chang Wildlife Sanctuary, Songkhla Province Southern Thailand. Science Asia, 26, 105-110. http://dx.doi.org/10.2306/scienceasia1513-1874.2000.26.105

[30] Gardner, S.M., Cabido, M.R., Valladares, G.R. and Diaz, S. (1995) The Influence of Habitat Structure on Arthropod Diversity in Argentine Semi-Arid CHACO Forest. Journal of Vegetation Science, 6, 349-356. http://dx.doi.org/10.2307/3236234

[31] Battist, A. (1998) Phytophagous Insect in Energy Flow of an Artificial Stand of Pinus nigra Arnold in Northern Italy. Redia, 71, 139-160.

[32] Brunetti, C.R. (2001) The Generation and Diversification of Butterfly Eyespot Colour Patterns. Journal of Cell Biology, 11, 1578-1585.

[33] Pollard, E. (1988) Temperature, Rainfall and Butterfly Numbers. Journal of Applied Ecology, 25, 819-828. http://dx.doi.org/10.2307/2403748

[34] Mittler, T.E, Radovsky, F.J. and Resh, V.H. (1995) Butterfly Conservation and Management. Annual Review of Entomology, 40, 57-83. http://dx.doi.org/10.1146/annurev.en.40.010195.000421 


\section{Appendix}

Appendix 1. Checklist of butterfly species in the university of Ibadan botanical garden.

\begin{tabular}{|c|c|c|}
\hline Scientific name & Common name & Family \\
\hline Ascia monuste & Great Southern White & Pieridae \\
\hline Ascia menaciae & Ramsden's Giant White & Pieridae \\
\hline Aphrissa gordatiana & Swainson’s sulphur & Pieridae \\
\hline Eurema portocoricensis & Porto Rican sulphur & Pieridae \\
\hline Eurema venusta & Llittle Sulphur & Pieridae \\
\hline Eurema dina & Bush sulphur & Pieridae \\
\hline Eurema messali & Shy sulphur & Pieridae \\
\hline Eurema nicippiformi & Black bordered orange & Pieridae \\
\hline Appias drusilla & Florida white & Pieridae \\
\hline Aphrissa statira & Migrant sulphur & Pieridae \\
\hline Kricogonia lyside & Guauacan sulphur & Pieridae \\
\hline Ascia monuste & Great southern white & Pieridae \\
\hline Phoebis argante & Apricot sulphur & Pieridae \\
\hline Ascia Josephina & Giant white & Pieridae \\
\hline Eurema adams & Adam’s sulphur & Pieridae \\
\hline Eurema gratiosa & Venezuelan sulphur & Pieridae \\
\hline Appias punctifera & D'almeida's white & Pieridae \\
\hline Pieris brassica & White butterfly & Pieridae \\
\hline Holimas missipus & The mimic & Nymphalidae \\
\hline Euptoieta hegesia & Mexican fritillary & Nymphalidae \\
\hline Prepona amphitoe & Poey’s eunica & Nymphalidae \\
\hline Eunica tatila & Silver king & Nymphalidae \\
\hline Euptoieta Claudia & Purple eunica & Nymphalidae \\
\hline Hypolimnas hysius & Variegated fritillary & Nymphalidae \\
\hline Mycelia antholia & Mimic & Nymphalidae \\
\hline Archmestra teleboas & Royal blue & Nymphalidae \\
\hline Anarthia amathea & Menetries & Nymphalidae \\
\hline Vanessa cardui & White peacock & Nymphalidae \\
\hline Siptoera stelenes & Painted lady & Nymphalidae \\
\hline Adelpha abyla & Malachite & Nymphalidae \\
\hline Dynmine argaea & Admiral & Nymphalidae \\
\hline Dynmine argaea & Bronzewing & Nymphalidae \\
\hline Philaethria dido & Bamboo page & Heliconidae \\
\hline Dione juno & Silver spot & Heliconidae \\
\hline Eueides melphis & Buff zebra & Heliconidae \\
\hline Dione vanilla & Gulf fritillary & Heliconidae \\
\hline Dryas iulia & Flambeau & Heliconidae \\
\hline Dryas cateri & Flambeau & Heliconidae \\
\hline Dione june & Fritillary & Heliconidae \\
\hline Danaus cleophile & Jamaican monarch & Danaidae \\
\hline Danaus glippus & The queen & Danaidae \\
\hline Danaus tethys & Monarch & Danaidae \\
\hline Danaus eresmusi & The soldier & Danaidae \\
\hline $\begin{array}{l}\text { Papilo humerus } \\
\text { Papilo oxynius }\end{array}$ & $\begin{array}{l}\text { Homerus swallowtail } \\
\text { Black swallowtail }\end{array}$ & $\begin{array}{l}\text { Papilonidae } \\
\text { Papilonidae }\end{array}$ \\
\hline Calisto confusa & Ringlets & Satyridae \\
\hline Calisto micheneri & Michener's ringlet & Satyridae \\
\hline Calisto lyceius & Rusty ringlet & Satyridae \\
\hline Calisto grannus & Darlington's ringlet & Satyridae \\
\hline Calisto loxias & Bate's ringlets & Satyridae \\
\hline Calisto nubile & Porto Rican ringlet & Satyridae \\
\hline Calisto herophile & Common ringlet & Satyridae \\
\hline Elecrostrymon angelia & Fulvous hairstick & Lycaenidae \\
\hline Pseudolyceana marsyas & Giant hairstick & Lycaenidae \\
\hline Greta diaphana & Jamaican clearwing & Ithiomidae \\
\hline Apodermia carteri & Carter's metal mark & Ridionidae \\
\hline
\end{tabular}

Source: Field survey, 2010. 